\title{
Seed dispersal distances: a typology based on dispersal modes and plant traits
}

\section{Pascal Vittoz ${ }^{1}$ and Robin Engler ${ }^{2}$}

${ }^{1}$ Faculty of Geosciences and Environment, University of Lausanne, Bâtiment Biophore, CH-1015

Lausanne, Switzerland; e-mail: pascal.vittoz@unil.ch (corresponding author)

${ }^{2}$ Department of Ecology and Evolution, University of Lausanne, Bâtiment Biophore, CH-1015 Lausanne, Switzerland; e-mail: robin.engler@unil.ch

\begin{abstract}
Vittoz P. and Engler R. 2007. Seed dispersal distances: a simplification for data analyses and models. Bot. Helv. 1xx: xx-xx.

The ability of plants to disperse seeds may be critical for their survival under the current constraints of landscape fragmentation and climate change. Seed dispersal distance would therefore be an important variable to include in species distribution models. Unfortunately, data on dispersal distances are scarce, and seed dispersion models only exist for some species with particular dispersal modes. To overcome this lack of knowledge, we propose a simple approach to estimate seed dispersal distances for a whole regional flora. We reviewed literature about seed dispersal in temperate regions and compiled data for dispersal distances together with information about the dispersal mode and plant traits. Based on this information, we identified seven "dispersal types" with similar dispersal distances. For each type, upper limits for the distance within which $50 \%$ and $99 \%$ of a species' seeds will disperse were estimated with the $80^{\text {th }}$ percentile of the available values. These distances varied 5000-fold among the seven dispersal types, but generally less than 50 -fold within the types. Thus, our dispersal types represented a large part of the variation in observed dispersal distances. The attribution of a dispersal type to a particular species only requires information that is already available in databases for most Central European species, i.e. dispersal vector (e.g. wind, animals), the precise mode of dispersal (e.g. dyszoochory, epizoochory), and species traits influencing the efficiency of dispersal (e.g. plant height, typical habitats). This typology could be extended to other regions and will make it possible to include seed dispersal in species distribution models.
\end{abstract}

Key words: Anemochory, anthropochory, autochory, hydrochory, plant migration, zoochory.

\section{Introduction}

Plant dispersal has attracted scientists since long ago (Darwin 1859; Schmidt 1918; Ridley 1930; Müller-Schneider 1983) and is particularly relevant with relation to human-driven environmental changes. For example, the survival of plant metapopulations in fragmented landscapes strongly depends on their dispersal potential (Fischer et al. 1996; Couvreur et al. 2004; Soons and Ozinga 2005), and the predicted global warming will require considerable migration rates for plant species to remain under similar climatic conditions (Malcolm et al. 2002).

Nevertheless, most models attempting to predict future plant distributions did not include dispersal, considering it as unlimited (Guisan and Theurillat 2000; Thuiller et al. 2005). Even without constraints on seed dispersal, these models already predict local extinctions, e.g. for isolated populations in mountains (Guisan and Theurillat 2000; Dirnbock et al. 2003; Thuiller et al. 2005). The actual extinction rates might be even higher if plant species cannot keep pace with rapid climate change due to limited dispersal. A more precise assessment of plant species extinction risk 
thus calls for the incorporation of plant dispersal potential (Pitelka et al. 1997; Davis et al. 1998; Ronce 2001).

Many studies have measured or estimated dispersal distances of plants in the field (Schneider 1935; Stöcklin and Bäumler 1996; Jongejans and Telenius 2001), and several mathematical models have been developed to estimate these distances (Tackenberg et al. 2003; Mouissie et al. 2005a; Nathan et al. 2005; Soons and Ozinga 2005). However, all of these studies have considered only a limited number of species or dispersal vectors. No dispersal distance data exist for a complete regional flora. Müller-Schneider (1986) reviewed dispersal vectors for the entire flora of Graubünden (East of Switzerland), but his work includes only few dispersal distances, most of which stem from anecdotal observations. Likewise, Bonn and Poschlod (1998) and Bonn (2004) wrote important syntheses on seed dispersal in Central Europe, but dispersal distances were only provided for a few dispersal vectors, mainly from anecdotal observations. It is thus currently impossible to conduct an assessment of the extinction risk of plant species under landscape fragmentation or global warming that would take dispersal into account.

The distance over which plants disperse seeds depends on plant traits as well as environmental conditions and varies strongly in time and space. This variability can be represented by a dispersal curve (dispersal kernel), which gives the proportion of seeds reaching a given distance (Mouissie et al. 2005a). However, it would be highly time consuming, if not impossible, to determine dispersal kernels for each species of a region. Thus, a simplified approach is needed to estimate dispersal distances for a whole regional flora. For example, if dispersal curves could be classified into a limited number of types with similar dispersal distances, and if plant species could be attributed to these "dispersal types" based on generally available plant traits, it would be possible to estimate dispersal kernels for all of them.

In this paper, we develop such an approach for the Swiss flora based on an extensive review of seed dispersal literature. We propose a typology of dispersal curves that can be applied to most Swiss and Central European plants. This typology could be extended to other regions and could be used to account for dispersal distances in species distribution models, enabling refined extinction risk assessments to be made for large numbers of species.

\section{Methods}

Plant dispersal is generally achieved through seeds. These can be enclosed in fruits or larger structures (usually called "diaspores"), but for the sake of simplification, the term "seed" will be used here as a general denomination.

Data for seed dispersal distances were compiled by reviewing a large proportion of available literature from Switzerland and other European countries, including monographies (MüllerSchneider 1983, 1986), reviews and research articles. Swiss species or close relatives were considered first priority, since our aim was to develop a typology for this region. However, other species were included when data available for Swiss species were insufficient to assess dispersal distances for certain dispersal modes (see below). The complete data set (ca. 300 values) is presented in Appendix 1. Species nomenclature follows Aeschimann et al. (1996) for the Swiss species.

The data set proved to be very heterogeneous. A small proportion of the distances had been determined through experiments, detailed field observations of seed or seedling distributions, or mathematical models. In such cases, it is often possible to calculate a dispersal kernel. However, most of the available data represent isolated and often anecdotal observations, from which a precise dispersal kernel cannot be derived. Some of these isolated observations clearly represented longdistance dispersal events (LDD), i.e. extreme values reached only by a very small minority of seeds. We therefore classified the data into three categories: (1) mean, mode or median values, (2) maximum values (99th percentiles of distribution kernels) and (3) values for LDD (clearly above the potential dispersal of $99 \%$ of the seeds). LDD values were excluded from the further analysis of the data. 
Our typology of dispersal curves was based on the dispersal modes recognised by MüllerSchneider (1983). The English translation of Müller-Schneider's German terminology generally follows Bonn et al. (2000). Müller-Schneider's (1983) classification of dispersal modes is primarily based on the dispersal vector (wind, water, animals, etc.), with additional subdivisions for the differing ways in which seeds are released and transported (e.g. on the fur or after ingestion by animals). Additional subdivisions were made for dispersal modes whose efficiency clearly depends on supplementary factors: plant height, pappus efficiency and environing vegetation structure for anemochory, and vector size for zoochory. Of the numerous possible subdivisions, only those considered most relevant were retained for our classification, as explained in the next section. This yielded a total of 21 refined dispersal modes (Tab. 1).

Tab. 1. Dispersal distances for seven dispersal types, estimated as the upper limits of the distances within which 50\% and $99 \%$ of the seeds of a plant population are dispersed. Note that actual dispersal distances will usually be lower than those given here (cf. Fig. 1). The dispersal distances were estimated from the $80^{\text {th }}$ percentile of the data compiled in Fig. 1 as well as additional qualitative information as explained in the text ('Dispersal modes and evaluation of published dispersal distances'). The dispersal modes included in each dispersal type are indicated; they are based on dispersal vectors (categories in parentheses) and plants traits that influence the efficiency of dispersal.

\begin{tabular}{|c|c|c|c|}
\hline \multirow[t]{2}{*}{ Type } & \multicolumn{2}{|c|}{ Dispersal distances [m] } & \multirow{2}{*}{ Corresponding dispersal modes } \\
\hline & $50 \%$ & $99 \%$ & \\
\hline 1 & 0.1 & 1 & $\begin{array}{l}\text { Blastochory (autochory) } \\
\text { Boleochory (anemochory) for species }<30 \mathrm{~cm} \\
\text { Ombrochory (hydrochory) }\end{array}$ \\
\hline 2 & 1 & 5 & $\begin{array}{l}\text { Ballochory (autochory) } \\
\text { Cystometeorochory (anemochory) } \\
\text { Chamaechory (anemochory) for fruits in grassland } \\
\text { Boleochory (anemochory) for species }>30 \mathrm{~cm}\end{array}$ \\
\hline 3 & 2 & 15 & $\begin{array}{l}\text { Pterometeorochory (anemochory) for herbs } \\
\text { Myrmecochory (zoochory) } \\
\text { Cystometeorochory (anemochory) ferns, Orchidaceae, Pyrolaceae, Orobanchaceae in forest } \\
\text { Trichometeorochory (anemochory) in forest or little efficient plumes } \\
\text { Epizoochory (zoochory) for small mammals }\end{array}$ \\
\hline 4 & 40 & 150 & $\begin{array}{l}\text { Chamaechory (anemochory) for seeds on snow or dry inflorescence } \\
\text { Pterometeorochory (anemochory) for trees } \\
\text { Dyszoochory (zoochory) for seeds not stocked and dispersed by small animals }\end{array}$ \\
\hline 5 & 10 & 500 & $\begin{array}{l}\text { Trichometeorochory (anemochory) in openland with efficient plumes } \\
\text { Cystometeorochory (anemochory) ferns, Orchidaceae, Pyrolaceae, Orobanchaceae in openland }\end{array}$ \\
\hline 6 & 400 & 1500 & $\begin{array}{l}\text { Dyszoochory (zoochory) for seeds stocked by large animals } \\
\text { Endozoochory (zoochory) for seeds eaten by birds and large vertebrates } \\
\text { Epizoochory (zoochory) by large mammals }\end{array}$ \\
\hline 7 & 500 & 5000 & Agochory (anthropochory) \\
\hline
\end{tabular}

Each dispersal distance in our data set was attributed to a dispersal mode, which was either the mode for which the distance had been determined (if mentioned in the original study) or the main dispersal mode of the species according to Müller-Schneider (1986). For species with more than one dispersal mode, distances that could not be clearly related to one of the modes were excluded from further data analysis. Dispersal types were then defined by grouping together dispersal modes with similar dispersal distances. This was done graphically by plotting the mean and maximal distances for each dispersal mode and identifying modes for which distances were in the same order of magnitude (Fig. 1).

Finally, we estimated upper limits of the distances, within which $50 \%$ and $99 \%$ of the seeds would disperse, by using the $80^{\text {th }}$ percentiles of the available mean, mode or median values and of the maximum values. Results were rounded to one significant digit to reflect their approximate nature. Our aim was to provide a conservative estimate of the dispersal constraint experienced by most species belonging to a dispersal type. Therefore we did not take the average of the published values (Fig. 1), but rather the 80th percentile of the distribution, as this allowed us to exclude the most extreme values. In some cases, a comparison of the results with qualitative information from the literature or with the authors' experience indicated that the available data were not quite 
representative for a certain dispersal type; values were then adjusted to obtain more realistic estimates. Such decisions are explained in the next section of the text for the individual dispersal modes.
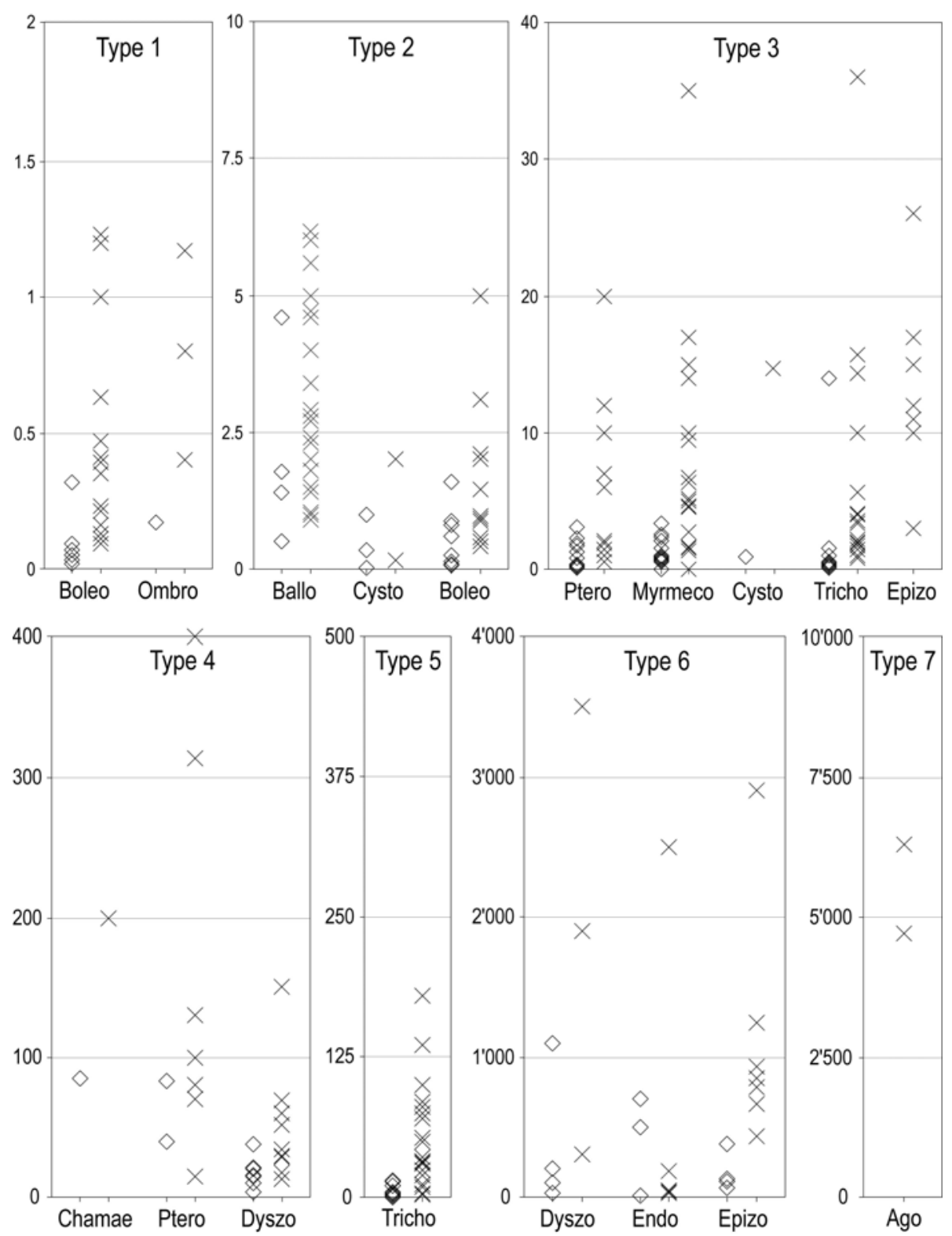

Fig. 1. Distribution of the dispersal distances found in literature (Appendix 1) for each dispersal mode, and subdivision of the data set into seven dispersal types. Diamonds are for mean, median or mode values, and crosses for $99 \%$ or maximum values (without long-distance dispersal). Four retained maximum values of type 5 are outside of the graph: 1714 m, 2112 m, $2194 \mathrm{~m}$ and $3673 \mathrm{~m}$. See Table 1 for definitions of the dispersal modes.

\section{Dispersal modes and evaluation of published dispersal distances}

\section{Autochory}

Autochorous plants disperse seeds without the help of an external vector. As a result, dispersal is limited to very short distances.

In blastochory, the stem of the plant grows or crawls on the ground to deposit the seeds as far as possible from the mother plant (e.g. Cymbalaria muralis, Polygonum aviculare, Veronica hederifolia; Müller-Schneider 1983). No data were found in the literature, but since the dispersal 
distance corresponds to the length of the stem, although species-specific, it is mostly very short and blastochory can hence be classified as type 1 (Tab. 1). This dispersal mode is, however, frequently completed by another one (Müller-Schneider 1986).

In ballochory, the explosion of the fruit ejects the seeds (ballistichory, ballistic dispersal). This explosion may be due to the turgescence of tissues (Impatiens sp., Cardamine sp.) or the tension between cells or different cell layers when the fruit is drying (Viola sp., Vicia sp., Lotus sp.). Published values are scattered and very variable (maximum 0.89-6.2 m; Fig. 1). Ballochory is classified in dispersal type 2 (Tab. 1).

Two further dispersal modes are barochory (seeds fall from the plant) and herpochory (seeds creep on the soil by the movement of organs in a succession of dry and wet conditions). However, since these strategies are not very efficient and always combined with other dispersal modes (Müller-Schneider 1986), they were not retained here.

\section{Anemochory}

Anemochorous seeds are dispersed by wind, often with the help of specific organs. This dispersal vector is the most studied as it is easily observable and measurable, at least over short distances (e.g. Bullock and Clarke 2000; Jongejans and Telenius 2001). Moreover, it relies on physical processes that can be translated into models (Tackenberg et al. 2003; Nathan et al. 2005; Soons and Ozinga 2005). Anemochory is subdivided according to the organs used to slow down the falling of seeds.

An air filled structure lightens small seeds in cystometeorochory (balloon-like). This dispersal mode is little studied. Maximum calculated distances are below $2 \mathrm{~m}$ (Soons and Ozinga 2005), but extreme values were measured up to $80 \mathrm{~m}$ for Calluna vulgaris (Bullock and Clarke 2000). This mode is certainly less efficient in forests, as wind is weaker, but it seemed useless to subdivide these already low values and thus cystometeorochory as a whole was attributed to type 2 .

The tiny seeds of Orchidaceae, Pyrolaceae and Orobanchaceae also have a low falling velocity (0.2-0.31 m/s for Orchidaceae; Müller-Schneider 1986). But only a calculated dispersion distance is available (median $0.95 \mathrm{~m}$ and 99-percentile $14.7 \mathrm{~m}$ for Cephalanthera damasonium, Soons and Ozinga 2005). However, because it is thought that very light seeds ( $<0.05 \mathrm{mg}$ ), even without corresponding adaptation for anemochory, are as efficient in wind as plumed seeds (Bonn and Poschlod 1998; Greene and Calogeropoulos 2002), we decided to classify these plant families with trichometeorochory in type 5 in openland but decreased to type 3 for forest species (Tab. 1). Fern spores can be included in cystometeorochory as well, but no data exist on their dispersal capacity except a calculated distance of $330 \mathrm{~km}$ for Lycopodium sp. based on its very low falling velocity $(1.8 \mathrm{~cm} / \mathrm{s}$; Schmidt 1918). This value seems exaggerated and in the absence of a more precise value, we attributed the ferns to the same types as orchids.

Plumed seeds are more efficient for wind dispersal. In trichometeorochory, seeds are completed with a hairy structure (e.g. pappus) to reduce falling velocity. These organs have very variable efficiency, however, with falling velocity varying from $8 \mathrm{~cm} / \mathrm{s}$ for Epilobium angustifolium to $165 \mathrm{~cm} / \mathrm{s}$ for Pulsatilla alpina (Müller-Schneider 1986). With an arbitrary separation at $30 \mathrm{~cm} / \mathrm{s}$, on the basis of our own observations, we distinguished species with less efficient plumes from those with efficient plumes (long plumes for small seeds). The first group has maximum distances between 1-15.7 (36) m, corresponding to type 3, and the second mainly between 20 and $179 \mathrm{~m}$ (Fig. 1). However, because some species have much higher calculated potentiality (e.g. up to $3600 \mathrm{~m}$ for Typha latifolia; Soons and Ozinga 2005), we retained intermediate values and assigned trichometeorochory to type 5 . Forest species were classified with trichometeorochory for less efficient plumes (type 3).

In pterometeorochory (or pterochory), seed dispersal is improved through wings. Trees are frequent in this category, but herbs are present as well, with a generally higher falling velocity. Because tree seeds are often large and easy to find, many available maximum dispersal distances are to be classified as LDD (e.g. Müller-Schneider 1983). Reviewed maximum distances ranged mainly between $80-314 \mathrm{~m}$ for trees and 1-12 m for herbs (Fig. 1). Pterometeorochory was thus classified as dispersal type 3 for herbs and type 4 for trees (Tab. 1). 
A much less studied dispersal mode is chamaechory, with diaspores rolling on the ground pushed by the wind. This diaspore can be either a circular-shaped fruit (Colutea arborescens, Astragalus alpinus), the fruit with calyx (Anthyllis vulneraria) or the complete, dry, inflorescence (synaptospermie of Eryngium campestre, Carlina acaulis). Chamaechory is especially common and efficient in steppes where nothing hampers dispersal (Müller-Schneider 1983), but it also occurs in mountains, with small seeds on snow (e.g. Saxifraga bryoides, S. exarata, Sempervivum montanum). The only available data are from Greene and Johnson (1997), who observed Betula alleghaniensis seeds and calculated a possible dispersion of $38 \mathrm{~m}$ for spherical 1mg-seeds on snow. Dispersal is usually restricted because seeds get stuck in irregularities. For chamaechory, we retained dispersal distance type 2 for fruits in grassland and type 3 for seeds on snow or carried by dry inflorescences (Tab. 1), but supplementary data would be necessary to get more precise values.

Boleochory (semachory) is another mode used by anemochorous plants. The small seeds without particular features are spread when the fruit is shaken by wind. At maturity, the stem of such plants is often rigid but elastic and sways in the wind, acting like a catapult. As animals or others may shake the capsules as well, some classify this mode independently (semachory; Bonn et al. 2000). Although small, the seeds are dense and have a high falling velocity $(1.2-5 \mathrm{~m} / \mathrm{s}$; MüllerSchneider 1983; Tackenberg 2001). Consequently, Soons and Ozinga (2005) calculated very short dispersal distances, generally $<0.5 \mathrm{~m}$, but without considering the catapult effect. Yet, this effect is certainly important, as measured distances sometimes exceed $10 \mathrm{~m}$ and are always higher than calculations for the same or close species. Since the catapult effect strongly depends on the stem size, we distinguished small species $(<30 \mathrm{~cm})$ whose seeds rarely go beyond $1 \mathrm{~m}$ (type 1$)$ from taller species $(>30 \mathrm{~cm}$ ), whose seeds may reach up to 3-5 $\mathrm{m}$ (type 2).

\section{Hydrochory}

Water can disperse seeds in various ways. In wetland plants, seeds are often light enough to float and move on rivers, lakes or ponds (nautochory of Alisma plantago-aquatica, Carex flava, C. elata, Iris pseudacorus, Sparganium sp.). Some seeds can float and survive for one year or more (Müller-Schneider 1983). Similarly, running water may carry many different types of seeds with heavy rains (bythisochory), sometimes to rivers and down to lowland areas. Bythisochory is complementary to other dispersal modes and randomly affects many different species dwelling on slopes. It is through this vector that high mountain species are frequently observed on gravel areas along rivers (Bill et al. 1999). Although the dispersal distances may be important, we did not attribute dispersal types to hydrochorous dispersal modes because distances are highly unpredictable and never documented. Moreover, nautochory is geographically limited and the bythisochory downslope restricted.

Rain may contribute to disperse seeds through the shock generated by the rain droplets hitting the fruits (ombrochory). Some species (e.g. Caltha palustris, Veronica serpyllifolia, Prunella vulgaris, Thlaspi perfoliatum) have developed fruit shapes and elastic fruitstalks in order to use this energy to eject seeds. Very few measurements are published for ombrochory, but they are all below or close to $1 \mathrm{~m}$ (type 1 ).

\section{Zoochory}

Animals are frequent and efficient vectors of dispersal, either voluntary when foraging or involuntary when carrying seeds on their fur or in their guts. Even though zoochory has often been observed and studied, estimating dispersal distances nevertheless remains difficult, as they highly depend on the disperser's behaviour. Zoochory can be split into four subcategories.

Many seeds are foraged as food by animals, which sometimes hide them as stock for the winter and forget about them, or lose them during transport (dyszoochory or dysochory). Vectors are mainly rodents or birds, and the dispersal distance is thus strongly dependent on the vector size. Small rodents, like voles or mice (Clethrionomys sp., Microtus sp., Apodemus sp.), generally disperse seeds less than $30 \mathrm{~m}$ (Cain et al. 1998; Xiao et al. 2004), and squirrels (Sciurus sp.) a little farther. In most cases, small birds disperse seeds by chance when feeding, for example when tits or woodpeckers are looking for a convenient place to break a nut. The rare available data do not 
exceed $60 \mathrm{~m}$. However, some larger species are more efficient dispersers by hiding fruits for winter stocks. The most famous examples are the nutcracker (Nucifraga carcyocatactes; Müller-Schneider 1986; Mattes 1992) and the jays (Garrulus glandarius; Müller-Schneider 1949; Kollmann and Schill 1996). The literature contains different data, but those are unfortunately too often extreme values (Mattes 1992), and most of the seeds are probably hidden within a few hundred meters. We thus retained type 4 when the vector of dyszoochory is a small animal and type 6 when seeds are stocked by a large animal (Tab. 1).

A particular case of dyszoochory is myrmecochory, or dispersal by ants. Generally interested by the elaiosome, a fatty appendix of the seeds, ants transport the seeds before eating the elaisome but leaving the rest of seed untouched and still able to germinate. Seeds may be used as building material for their nest as well, without loosing their germination potential (Müller-Schneider 1963; Cherix 1981). This dispersal mode has been extensively studied in the world, but only rarely are distances available for European plants, and they rarely exceed $10 \mathrm{~m}$. Some exceptional observations nevertheless give values up to 70 m (Müller-Schneider 1983; Bonn and Poschlod 1998), and myrmecochory was hence classified as type 3.

Animals are important dispersal vectors when eating fruit or even the complete plant (Janzen 1984), and seeds go undamaged through their gut (endozoochory). Many authors have studied the survival of the seeds through vertebrate guts and the importance of this vector (see Janzen 1984; Pakeman 2001). As the consumer can be anything from a worm to a snail, mammal or bird, dispersal distance is very dependent on its size and mobility. No data exist for small animals and they are scarce and mostly anecdotal for larger ones such as birds or foxes. Models based on seedretention time is a possibility for getting dispersal distance estimates, but they are still rare (e.g. Hickey et al. 1999; Vellend et al. 2003), and seed-retention time depends on seed and animal species (Bonn 2004; Mouissie et al. 2005b). Moreover, these models usually calculate linear distance, but animals generally live in a limited territory and do not move linearly. We chose type 6 to translate potential dispersal by large mammals or birds (Tab. 1).

Seeds are also frequently transported by animals in fur (epizoochory). This is partly the result of specific structures, with seeds or fruits bearing hooks or glandulous hairs (Galium aparine, Arctium sp., Saxifraga tridactylites,...) but seeds without an appendix can attach to fur as well (e.g. Fischer et al. 1996; Mouissie et al. 2005a; Römermann et al. 2005). Observations in natural conditions are rare and most of the data are from retention time measurements with sheep, cattle or dummies (e.g. Fischer et al. 1996; Mouissie et al. 2005a). Although small rodents may disperse seeds as well (Kiviniemi and Telenius 1998), the most efficient epizoochory is obtained with taller animals. The maximum distance calculated by models based on seed retention time in fur is between 435-1242 m, but can be longer with sheep whose long and curled wool is particularly efficient at retaining seeds (Fischer et al. 1996; Mouissie et al. 2005a). The habitual dispersal distance is thus estimated as type 6 for epizoochory with large animals, but much longer distances can occasionally be achieved by sheep during transhumance (Fischer et al. 1996).

\section{Anthropochory}

Seed dispersal by humans certainly always occurred, but it strongly increased during the last centuries, and became particularly important a few decades ago with the market globalisation and the intercontinental transport of goods (e.g. Hodkinson and Thompson 1997; Tinner and Schumacher 2004).

Müller-Schneider $(1983,1986)$ distinguished three modes of anthropochory: plants or seeds being sold for agriculture and gardening (ethelochory), seeds being involuntarily mixed with the previous ones (speirochory), or seeds travelling hidden in goods, cars, soil under soles, with hay, etc. (agochory). All three means can potentially lead to very long dispersal distances and are, for example, responsible for the advent of neophytes in Switzerland and Europe. But while ethelochory and speirochory mostly concern urban and cultivated areas, agochory is probably more important in natural or semi-natural ecosystems. Seed dispersal distance through anthropochory is strongly dependent on the type of human activity but, in general, agricultural activities are the most susceptible to spreading seeds in semi-natural ecosystems due to movements between fields or 
meadows (McCanny and Cavers 1988). We can thus limit most of the dispersal distance to the approximate size of a farming property (type 7).

\section{Dispersal types and estimated dispersal distances}

Despite the heterogeneous origin of the data compiled here, dispersal distances for individual dispersal modes proved to be rather consistent, mostly belonging to the same order of magnitude. Across the entire data set, maximal dispersal distances ranged between 0.09 and $6300 \mathrm{~m}$ (LDD excluded), corresponding to a factor of 70'000 between the highest and lowest value. After classification into dispersal types, this variation was reduced to a factor of 10 for type 1, 40 for type 2, 70 for type 3, 20 for type 4, 1700 for type 5, 200 for type 6, and 1 for type 7 (very few data). This variability within types may still seem considerable, but it is small compared to the 5000 -fold difference in dispersal distances between types 1 and 7. Furthermore, the high value for type 5 (trichometeorochory with efficient plumes) reflects the high variability of pappus efficiency in this category and the high variability found within species (e.g. Taraxacum officinale). The typology presented here thus expresses a large part of the variation in seed dispersal distances. Accordingly, attributing species to dispersal types makes it possible to describe interspecific variation in dispersal capacity.

The estimated distances in Table 1 do of course not represent the dispersal kernel of one single plant, nor even the mean pluri-annual dispersal kernel of a particular plant population. They were estimated as the upper limits $\left(80^{\text {th }}\right.$ percentile) of the dispersal distance values (Fig. 1$)$, meaning that they represent the dispersal potential of the plant species grouped into a dispersal type. Most plant populations will disperse over smaller distances than those indicated in Table 1, but data and models indicate that they could potentially disperse $50 \%$ or $99 \%$ of their seeds inside the retained distances. Estimating upper limits to dispersal, rather than average distances, is justified when dispersal is included as a possible constraint to species survival in predictive models of species distributions. In this case, upper dispersal limits yield a constraint that holds for all species of a certain dispersal type. This ensures that dispersal constraints will not be overestimated.

\section{Alternative dispersal modes}

Multiple dispersal vectors

About 40\% of the species considered by Müller-Schneider (1986) have two or more dispersal modes. The species can either use them alternatively depending on the available vector (Picea abies is anemochorous or dyszoochorous with the red squirrel or some birds) or on its phenology (Urtica dioica is anemochorous and avoided by animals when green but grazed and endozoochorous once dry), or it can rely on them successively to improve dispersal (Leucojum vernum is firstly blastochorous and lately myrmecochorous; Müller-Schneider 1983).

If the most obvious dispersal mode can often be inferred from the seed or fruit morphology, finding out what the alternative dispersal modes of a species are generally requires precise observations. For example, Campanula rotundifolia and Primula elatior are considered endozoochorous by Müller-Schneider (1986) but not Campanula scheuchzeri or Primula veris, which are only described as boleochor species. This difference, probably incorrect, strongly affects their dispersal potential, as endozoochory is much more efficient than boleochory (Tab. 1), and shows the gaps in our attainments.

Recent results showed that this problem appears with other dispersal modes too. Tackenberg et al. (2003) modelled wind dispersion of seeds on the basis of their falling velocity and release height. They concluded that some species normally not considered as anemochorous could be as efficient as species traditionally thought-of as wind dispersed. Another example is given by Higgins et al. (2003), who demonstrated that a $7.8 \mathrm{~g}$ Carya glabra nut is able to disperse $647 \mathrm{~m}$ if uplifted by strong winds. Similarly, epizoochory concerns more species than what diaspore morphology indicates, and many plumed seeds for anemochory or smooth seeds are transported as well (Fischer et al. 1996; Couvreur et al. 2004; Mouissie et al. 2005a; Römermann et al. 2005). 
When multiple vectors are recognized, it is logical to classify the species into the dispersal distance type corresponding to the most efficient one (e.g. dyszoochory for Picea abies or endzoochory for Campanula rotundifolia). But this can not consider the unsuspected supplementary vectors.

\section{Long-distance dispersal (LDD) and Reid's paradox}

The inadequacy between the dispersal potential of plants and their post-glacial recolonisation, also known as "Reid's paradox" (Clark et al. 1998), is an issue that has been recognized for a long time (Reid 1899; Skellam 1951; Cain et al. 1998). Lang (1994) calculated the migration rate of anemochorous trees through Europe and found per-generation travel distances of 0.5-5 km for Tilia sp, 1.2-9 km for Abies alba, 10-20 km for Acer sp. or 15-60 km for Pinus sylvestris. This is much higher than the $200 \mathrm{~m}$ considered in table 1 for $99^{\text {th }}$ percentile. Similarly, dyszoochorous species with an estimated potential dispersal of $1 \mathrm{~km}$ (Tab. 1) showed post-glacial colonisation rate of 2.2$15 \mathrm{~km}$ per generation for Quercus sp. or 7-14 km for Fagus sylvatica (Lang 1994). However, as was recently found for Fagus sylvatica (Magri et al. 2006), it is possible that those recolonisation rates are overestimated because some glacial refugia remain yet unknown (Clark et al. 1998; Stewart and Lister 2001; Pearson 2006).

Recent data for invasive species show similar high rates of spread for many species. Pyšek and Hulme (2005) listed 16 species with colonisation superior to $1 \mathrm{~km} / \mathrm{y}$ for long-distance dispersal, with a maximum of $167 \mathrm{~km} \mathrm{yr}^{-1}$. They showed that the rate of spread may be similarly high for wind, water or animal dispersed plants. But the landscape structure and human activity influence this spreading, with higher rates found in densely inhabited or particularly economically active regions (Williamson et al. 2005).

A solution to resolve this discrepancy between estimated dispersal distances and observed migration rates is to consider that dispersal vectors indicated by seed morphology mainly explain the short dispersal distances, with the rare events responsible for LDD relying on other vectors (Cain et al. 1998; Higgins et al. 2003). For example, 78\% of the plants that arrived on Surtsey island (Iceland) were transported by water when only one quarter of those taxa were morphologically adapted for water dispersal (Higgins et al. 2003). Birds can transport seeds in mud sticking to their feet (Carlquist 1967), ingest some anemochorous seeds (Wilkinson 1997) or use them to build their nest (Salix sp. or Clematis vitalba; Müller-Schneider 1983; Dean et al. 1990). Seed plumes or pappus are not only very efficient for wind dispersal (anemochory), but also for fixing on animal fur (Fischer et al. 1996; Couvreur et al. 2004). Finally, humans also are efficient involuntary dispersal vectors nowadays (e.g. Hodkinson and Thompson 1997), but were also vectors during the post-glacial recolonisation, like for Corylus avellana or agricultural weeds (Braun-Blanquet 1970; Lang 1994; Clark et al. 1998).

Taking into account the influence of LDD on plant migration in a better manner can possibly be achieved by improving the models fitted on dispersal observations (Kot et al. 1996; Clark et al. 1998; Higgins and Richardson 1999). These improved models would help to propose dispersal distance values for the remaining $1 \%$ of the seeds (Tab. 1). But up to now, the necessary values for this improvement are missing for most species and dispersal modes, and hence we cannot propose realistic values for our dispersal distance types. Yet, even though this improvement in LDD estimation would be achieved, it could explain only a part of LDD, as the randomness of unconventional dispersal vectors cannot be standardised for all species. The importance of these accidental dispersions is not known in nature. It may be an important factor for colonising large, new areas (Higgins et al. 2003) or disturbed areas (Bergelson et al. 1993; Williamson et al. 2005), but it is certainly less frequent in closed, natural vegetation. Takahashi and Kamitani (2004) observed the colonisation of native herbaceous species in an artificial pine forest. They found that the distances dispersed by species using various dispersal vectors were similar to what we proposed for our dispersal types (Tab. 1), thus indicating that the unconventional dispersal vectors were certainly not predominant. 


\section{Conclusions}

Although the data compiled in this paper are certainly incomplete, they are the most comprehensive data set currently available for the Central European flora. Our method for estimating dispersal distances based on dispersal types is less precise than the calculation of species-specific dispersal models. On the other hand, our typology can be applied to almost all European plant species, which is not the case of a species specific model. As discussed above, our typology is able to represent a large fraction of the interspecies variation in dispersal distances as long as long-distance dispersal is ignored.

Future research on dispersal mechanisms as well as the inclusion of our estimates in species distribution models will show whether the use of this typology leads to predicted migration rates that are close to the observed ones. If differences prove to be important for some of the dispersal types, our typology could be improved by adjusting the corresponding dispersal distances. Alternatively, if observed migration rates are consistently underestimated by the use of our typology, this would suggest that long-distance dispersal is much more important for long-term plant displacements than the dispersal modes presented here. Our typology is therefore certainly not the final one, but an important basis for improving predictive models of species distributions.

\section{Résumé}

La capacité des plantes à disperser est un facteur important à leur survie dans un paysage fragmenté ou sous l'influence des changements climatiques. Il est donc important de pouvoir tenir compte des distances de dispersion dans les modèles de répartition des espèces, mais les valeurs existantes, mesurées ou calculées, sont rares. Nous proposons donc une approche simple permettant d'estimer ces distances pour l'ensemble d'une flore régionale. Nous avons recherché dans la littérature les données disponibles pour la flore des régions tempérées (avant tout pour les espèces suisses) et associé les distances de dispersion trouvées avec le mode de dispersion et des traits biologiques. Sept types de dispersion ont pu être identifiés sur la base de ces informations, chaque type regroupant des espèces avec des distances de dispersion proches. Les distances à l'intérieur desquelles $50 \%$ et $99 \%$ des graines sont dispersées ont été estimées sur la base du 80 e percentile des valeurs disponibles au sein de chaque type. Ces distances varient d'un facteur 5000 entre les sept types de dispersion, alors que les valeurs à disposition pour chaque type ne dépassent généralement pas un facteur de 50. Nos types de dispersion conservent donc une large part de la variation existante dans la dispersion des graines. L'attribution d'une espèce à un type de dispersion ne nécessite que des informations couramment disponibles, comme le vecteur de dispersion (vent, animaux, ...), le mode précis de la dispersion (dyszoochorie, épizoochorie, ...) et des traits biologiques influençant la dispersion (hauteur de la plante, habitat, ...). Cette typologie pourrait être étendue à d'autres régions et permet d'inclure la dispersion des graines dans les modèles de répartition des espèces.

This research has been partly supported by the Federal Office for the Environment. We are grateful to Christophe Randin and Antoine Guisan for useful advice and discussion. We thank S. Güsewell, J. Kollmann and an anonymous reviewer for their useful comments on an earlier version of the manuscript.

\section{Bibliographie}

Aeschimann D., Heitz C., Palese R., Perret P. et Moser D.M. 1996. Index synonymique de la Flore de Suisse et territoires limitrophes (ISFS). CRSF, Genève.

Bergelson J., Newman J.A. and Floresroux M.E. 1993. Rates of weed spread in spatially heterogeneous environments. Ecology 74: 999-1011.

Bill H.-C., Poschlod P., Reich M. and Plachter H. 1999. Experiments and observations on seed dispersal by running water in Alpine floodplain. Bull. Geobot. Inst. ETH 65: 13-28.

Bonn S. 2004. Dispersal of plants in the Central European landscapes - dispersal processes and assessment of dispersal potential exemplified for endozoochory. PhD thesis, Universität Regensburg.

Vittoz and Engler (2007)

Botanica Helvetica 117: 109-124 
Bonn S. und Poschlod P. 1998. Ausbreitungsbiologie der Pflanzen Mitteleuropas. Quelle and Meyer, UTB, Wiesbaden.

Bonn S., Poschlod P. and Tackenberg O. 2000. "Diasporus" - a database for diaspore dispersal. Concept and applications in case studies for risk assessment. Z. Ökologie u. Naturschutz 9: 85-97.

Braun-Blanquet J. 1970. Associations messicoles du Languedoc. Leur origine, leur âge. Melhoramento 22: 55-75.

Bullock J.M. and Clarke R.T. 2000. Long distance seed dispersal by wind: measuring and modelling the tail of the curve. Oecologia 124: 506-521.

Cain M.L., Damman H. and Muir A. 1998. Seed dispersal and the Holocene migration of woodland herbs. Ecol. Monogr. 68: 325-347.

Carlquist S. 1967. The biota of long distance dispersal. V. Plant dispersal to Pacific islands. Bull. Torrey Bot. Club 94: 129-162.

Cherix D. 1981. Contribution à la biologie et à l'écologie de Formica lugubris Zett. (Hymenoptera, Formicidae). Le problème des super-colonies. Thèse de doctorat, Université de Lausanne.

Clark J.S., Fastie C., Hurtt G., Jackson S.T., Johnson C., King G.A., Lewis M., Lynch J., Pacala S., Prentice C., Schupp E.W., Webb T. and Wyckoff P. 1998. Reid's paradox of rapid plant migration (dispersal theory and interpretation of paleoecological records). Bioscience 48:13-24.

Couvreur M., Christiaen B., Verheyen K. and Hermy M. 2004. Large herbivores as mobile links between isolated nature reserves through adhesive seed dispersal. Appl. Veg. Sci. 7: 229-236.

Darwin C.R. 1859. The origin of species. John Murray, London.

Davis A.J., Jenkinson L.S., Lawton J.H., Shorrocks B. and Wood S. 1998. Making mistakes when predicting shifts in species range in response to global warming. Nature 391: 783-786.

Dean W.R.J., Milton S.J. and Siegfried W.R. 1990. Dispersal of seeds as nest material by birds in semiarid karoo shrubland. Ecology 71: 1299-1306.

Dirnbock T., Dullinger S. and Grabherr G. 2003. A regional impact assessment of climate and land-use change on alpine vegetation. J. Biogeogr. 30: 401-417.

Fischer S.F., Poschlod P. and Beinlich B. 1996. Experimental studies on the dispersal of plants and animals on sheep in calcareous grassland. J. Appl. Ecol. 33: 1206-1222.

Greene D.F. and Calogeropoulos C. 2002. Measuring and modelling seed dispersal of terrestrial plants. In: Bullock J.M., Kenward R.E. and Hails R.S. (eds) Dispersal ecology. The $42^{\text {nd }}$ Symposium of the British Ecological Society held at the University of Reading 2-5 April 2001. Blackwell, Oxford, 3-23.

Greene D.F. and Johnson E.A. 1997. Secondary dispersal of tree seeds on snow. J. Ecol. 85: 329-340.

Guisan A. and Theurillat J.-P. 2000. Assessing alpine plant vulnerability to climate change: a modeling perspective. Integrated Assessment 1: 307-320.

Hickey J.R., Flynn R.W., Buskirk S.W., Gerow K.G. and Willson M.F. 1999. An evaluation of a mammalian predator, Martes americana, as a disperser of seeds. Oikos 87: 499-508.

Higgins S.I., Nathan R. and Cain M.L. 2003. Are long distance dispersal events in plants usually caused by nonstandard means of dispersal? Ecology 84: 1945-1956.

Higgins S.I. and Richardson D.M. 1999. Predicting plant migration rates in a changing world: the role of long-distance dispersal. Am. Nat. 153: 464-475.

Hodkinson D.J. and Thompson K. 1997. Plant dispersal: The role of man. J. Appl. Ecol. 34: 1484-1496.

Janzen D.H. 1984. Dispersal of small seeds by big herbivores: Foliage is the fruit. Am. Nat. 123: 338-353.

Jongejans E. and Telenius A. 2001. Field experiments on seed dispersal by wind in ten umbelliferous species (Apiaceae). Plant Ecology 152: 67-78

Kiviniemi K. and Telenius A. 1998. Experiments on adhesive dispersal by wood mouse: seed shadows and dispersal distances of 13 plant species from cultivated areas in southern Sweden. Ecography 21: 108-116.

Kollmann J. and Schill H.P. 1996. Spatial patterns of dispersal, seed predation and germination during colonization of abandoned grassland by Quercus petraea and Corylus avellana. Vegetatio 125: 193-205.

Kot M., Lewis M.A. and van den Driessche P. 1996. Dispersal data and the spread of invading organisms. Ecology 77 : 2027-2042.

Lang G. 1994. Quartäre Vegetationsgeschichte Europas. Methoden und Ergebnisse. Fischer Verlag, Jena.

Magri D., Vendramin G.G., Comps B., Dupanloup I., Geburek T., Gomory D., Latalowa M., Litt T., Paule L., Roure J.M., Tantau I., van der Knaap W.O., Petit R.J. and de Beaulieu J.L. 2006. A new scenario for the Quaternary history of European beech populations: palaeobotanical evidence and genetic consequences. New Phytol. 171: 199-221.

McCanny S.J. and Cavers P.B. 1988. Spread of proso millet (Panicum miliaceum L.) in Ontario, Canada. II. Dispersal by combines. Weed Res. 28: 67-72. 
Malcolm J.R., Markham A., Neilson R.P. and Garaci M. 2002. Estimated migration rates under scenarios of global climate change. J. Biogeogr. 29: 835-849.

Mattes H. 1982. Die Lebensgemeinschaft von Tannenhäher, Nucifraga caryocatactes (L.), und Arve, Pinus cembra L.. Ber. Eidg. Anst. Forstl. Versuchswes. 241: 1-74.

Mouissie A.M., Lengkeek W. and van Diggelen R. 2005a. Estimating adhesive seed-dispersal distances: field experiments and correlated random walks. Funct. Ecol. 19: 478-486.

Mouissie A.M., van der Veen C.E.J., Veen G.F. and van Diggelen R. 2005b. Ecological correlates of seed survival after ingestion by fallow deer. Funct. Ecol. 19: 284-290.

Müller-Schneider P. 1949. Unsere Vögel als Samenverbreiter. Orn. Beob. 46: 120-123.

Müller-Schneider P. 1963. Neue Beobachtungen über Samenverbreitung durch Ameisen. Ber. Schweiz. Bot. Ges. 73: 153-160.

Müller-Schneider P. 1983. Verbreitungsbiologie (Diasporologie) der Blütenpflanzen. 3. Aufl. Veröff. Geobot. Inst. ETH Stiftung Rübel Zürich 61: 1-226.

Müller-Schneider P. 1986. Verbreitungsbiologie der Blütenpflanzen Graubündens. Veröff. Geobot. Inst. ETH Stiftung Rübel Zürich 85: 1-263.

Nathan R., Sapir N., Trakhtenbrot A., Katul G.G., Bohrer G., Otte M., Avissar R., Soons M.B., Horn H.S., Wikelski M. and Levin S.A. 2005. Long-distance biological transport processes through the air: can nature's complexity be unfolded in silico? Diversity Distrib. 11: 131-137.

Pakeman R.J. 2001. Plant migration rates and seed dispersal mechanisms. J. Biogeogr. 28: 795-800.

Pearson R.G. 2006. Climate change and the migration capacity of species. Trends Ecol. Evol. 21: 111-113.

Pitelka L.F., Gardner R.H., Ash J. Berry S., Gitay H., Noble I.R., Saunders A., Bradshaw R.H.W., Brubaker L., Clark J.S., Davis M.B., Sugita S., Dyer J.M., Hengeveld R., Hope G., Huntley B., King G.A., Lavorel S., Mack R.N., Malanson G.P., McGlone M., Prentice I.C. and Rejmanek M. 1997. Plant migration and climate change. Am. Sci. 85: 464-473.

Pyšek P. and Hulme P.E. 2005. Spatio-temporal dynamics of plant invasions: linking pattern to process. Ecoscience 12: 302-315.

Reid C. 1899. The origin of the British flora. Dulau, London.

Ridley H.N. 1930. The dispersal of plants throughout the world. Reeve, Ashford.

Römermann C., Tackenberg O. and Poschlod P. 2005. How to predict attachment potential of seeds to sheep and cattle coat from simple morphological seed traits. Oikos 110: 219-230.

Ronce O. 2001. Understanding plant dispersal and migration. Trends Ecol. Evol. 16: 663.

Schmidt W. 1918. Die Verbreitung von Samen und Blütenstaub durch die Luftbewegung. Oesterr. Bot. Z. 67: 313-328.

Schneider S. 1935. Untersuchungen und Samenschleudermechanismen verschiedener Rhoeadales. Jahrb. Wiss. Botanik 81: 663-704.

Skellam J.G. 1951. Random dispersal in theoretical populations. Biometrika 38: 196-218.

Soons M.B. and Ozinga W.A. 2005. How important is long-distance seed dispersal for the regional survival of plant species? Diversity Distrib. 11: 165-172.

Stewart J.R. and Lister A.M. 2001. Cryptic northern refugia and the origins of the modern biota. Trends. Ecol. Evol. 16: 608-613.

Stöcklin J. and Bäumler E. 1996. Seed rain, seedling establishment and clonal growth strategies on a glacier foreland. J. Veg. Sci. 7: 45-56.

Tackenberg O. 2001. Methoden zur Bewertung gradueller Unterschiede des Ausbreitungspotentials von Pflanzenarten. $\mathrm{PhD}$ thesis, Philipps-Universität Marburg.

Tackenberg O., Poschlod P. and Bonn S. 2003. Assessment of wind dispersal potential in plant species. Ecol. Monogr. 73: 191-205.

Takahashi K. and Kamitani T. 2004. Effect of dispersal capacity on forest plant migration at landscape scale. J. Ecol. 92: 778-785.

Thuiller W., Lavorel S., Araújo M.B., Sykes M.T. and Prentice I.C. 2005. Climate change threats to plant diversity in Europe. Proc. Natl. Acad. Sci. U.S.A. 102: 8245-8250.

Tinner U. and Schumacher H. 2004. Flora auf Bahnhöfen der Nordostschweiz. Bot. Helv. 114: 109-125.

Vellend M., Myers J.A., Gardescu S. and Marks P.L. 2003. Dispersal of Trillium seeds by deer: implications for longdistance migration of forest herbs. Ecology 84: 1067-1072.

Wilkinson D.M. 1997. Plant colonization: are wind dispersed seeds really dispersed by birds at large spatial and temporal scales? J. Biogeogr. 24: 61-65.

Williamson M., Pyšek P., Jarošík V. and Prach K. 2005. On the rates and patterns of spread of alien plants in the Czech Republic, Britain, and Ireland. Ecoscience 12: 424-433. 
Xiao Z., Zhang Z. and Wang Y. 2004. Dispersal and germination of big and small nuts of Quercus serrata in a subtropical broad-leaved evergreen forest. Forest Ecol. Manage. 195: 141-150.

\section{Appendix}

App. 1. Literature data on seed dispersal distances. The examples are mainly from the Swiss flora, except when data were insufficient for certain dispersal modes. Some supplementary species were thus added, mostly from temperate regions. Asterisks indicate values that were considered to represent long-distance dispersal and were therefore excluded from data analysis.

This Appendix can be downloaded freely from http://www.birkhauser.ch/BH, "Electronic supplementary material". 


Species
Autochory
Ballochory
Cardamine amara
Cardamine impatiens
Cardamine pratensis
Cardamine resedifolia
Cardamine resedifolia
Geranium maculatum
Geranium maculatum
Geranium molle
Geranium robertianum
Geranium rotundifolium
Geranium sylvaticum
Impatiens parviflora
Lathraea clandestina
Lathyrus vernus
Mercurialis annua
Mercurialis perennis
Mercurialis perennis
Oxalis acetosella
Oxalis acetosella
Viola arvensis
Viola canina
Viola riviniana
Viola stricta

\section{Anemochory
Cystometeorocho}

$$
\begin{gathered}
\text { Cystometeorochory } \\
\text { Calluna vulgaris } \\
\text { Calluna vulgaris } \\
\text { Erica cinerea } \\
\text { Sanguisorba minor } \\
\text { Orchidaceae } \\
\text { Cephalanthera damasonium } \\
\text { Trichometeorochory } \\
\text { Little efficient }
\end{gathered}
$$

Anthoxanthum odoratum

Carex frigida

Carlina vulgaris

Carlina vulgaris

Crepis paludosa
Geum reptans

Hieracium aurantiacum

Hieracium murorum aggr.

Hieracium murorum aggr.

Hieracium pilosella

Hieracium sabaudum

Leontodon autumnalis

Picris hieracioides

Pulsatilla sp.

Senecio jacobea

Senecio jacobea

Senecio vulgaris

Senecio vulgaris

Tragopogon pratensis

Forest plants

Mycelis muralis

Highly efficient

Adenostyles leucophylla

Carduus nutans

Carduus nutans

Cirsium arvense

Cirsium arvense

Cirsium spinosissimum

Cirsium vulgare
Cirsium vulgare

Clematis sp.

Clematis vitalba

Epilobium angustifolium

Epilobium ciliatum

Epilobium fleischeri

Epilobium hirsutum

Epilobium montanum

Erigeron acer s.I.

Erigeron annuus

Eupatorium cannabinum

Hieracium staticifolium

Myricaria germanica

Phragmites australis

Poa nemoralis

Salix sp.

Solidago gigantea

Solidago virgaurea subsp. minuta

Taraxacum officinale

Taraxacum officina

Tussilago farfara

Tussilago farfara

Typha angustifolia

Typha latifolia

Herbs
Heromete

Agrostis rupestris

Angelica sylvestris

Angelica sylvestris

Bromus inermis

Bromus sterilis

Heracleum sphondylium

Laserpitium latifolium

Oxyria digyna

Pastinaca sativa

Peucedanum palustre

Peucedanum palustre

Rumex acetosa

Rumex acetosa
Rumex scutatus

Scabiosa columbaria

Selinum carvifolia

Selinum carvifolia
Distance [m]
ong-distance dispersal

Remarque (without indication, the values are measured)

Reference

$\begin{array}{cl}1.4 & \text { Maximum } \\ 2 & \text { Maximum } \\ 2.4 & \text { Maximum } \\ 1.04 & \text { Maximum } \\ <1 & \text { Maximum } \\ 1.4 / 6.2 & \text { Mode and maximum } \\ 4.6 / 5.6 & \text { Mode and maximum } \\ 1.78 / 2.8 & \text { Mean and maximum } \\ 6 & \text { Maximum } \\ 1.8 & \text { Maximum } \\ 2.7 & \text { Maximum } \\ 3.4 & \text { Maximum } \\ 4 & \text { Maximum } \\ 1.5 & \text { Maximum } \\ 2.9 & \text { Maximum } \\ 4 & \text { Maximum } \\ 0.89 & \text { Maximum } \\ 2.3 & \text { Maximum } \\ 5 & \text { Maximum } \\ 2.4 & \text { Maximum } \\ 4.7 & \text { Maximum } \\ 4.6 & \text { Maximum } \\ 0.5 / 3.4 & \text { Mode and maximum }\end{array}$

$1 / 80^{*}$
$0.35 / 2$

$1 / 80^{*}$

$0.03 / 0.17$

$0.95 / 14.7$

$90 \%$ of the seeds and maximum

Calculated median and 99-percentile

$90 \%$ of the seeds and maximum

Calculated median and 99-percentile

Calculated median and 99-percentile

$0.3 / 2 \quad$ Mode and maximum

$<1 \quad$ Maximum

$0.22 / 1.7 \quad$ Calculated median and 99-percentile

1.47 Maximum with a $16.4 \mathrm{~km} / \mathrm{h}$ wind

$0.31 / 2.2 \quad$ Calculated median and 99-percentile

$4 \quad$ Maximum

$0.27 / 1.9 \quad$ Mode an maximum

$0.21 / 1.7$
$1.5 / 15.7$

$0.5 / 15.7$
$0.12 / 0.81$

$0.12 / 0.81$
$0.40 / 3.54$

$0.40 / 3.5$

$80^{*}$

$0.49 / 4.1$
$14 / 36$

$0.34 / 2$

$0.41 / 3.4$

$0.99 / 14.3$

$0.58 / 5.6$

85

$0.83 / 9.6$
$10 / 40-100$

$10 / 40-100$

$2.0 / 53.4$

11.4

$1.8 / 31.6$

$1 / 32$

100
$10.2 / 100$
$7.48 / 2112$

$7.48 / 2112$

50
$4 / 136$
$1.6 / 49.6$

$4 / 136$
$1.6 / 49.6$
75

75

$1.6 / 35.4$

$1.6 / 23.7$

75

100

$3.9 / 1714$
50
100

100

$4.2 / 136$

$0.22 / 2.2$

50

$1>4000$

$11.3 / 2194$

$14.7 / 3673$

Maximum

Calculated median and 99-percentile

Calculated median and 99-percentile

Calculated median and 99-percentile

Calculated median and 99-percentile

Maximum

Calculated median and 99-percentile

Mode and maximum

Calculated median and 99-percentile

Mean and maximum

Calculated median and 99-percentile

Calculated median and 99-percentile

Calculated median and 99-percentile

Maximum

and 99-percentile

Mode and maximum of different measures

Calculated median and 99-percentile

Maximum with a $16.4 \mathrm{~km} / \mathrm{h}$ wind

Maximum

Calculated median and 99-percentile

Mean and maximum

Calculated median and 99-percentile

Calculated median and 99-percentile

Calculated median and 99-percentile

Maximum

Calculated median and 99-percentile

Calculated median and 99-percentile

Maximum

Calculated median and 99-percentile

Calculated median and 99-percentile

Calculated median and 99-percentile

Maximum

Calculated median and 99-percentile

Maximum

Maximum

Calculated median and 99-percentile

Maximum

Calculated median and 99-percentile

Maximum

Mode and maximum

Calculated median and 99-percentile

Calculated median and 99-percentile

$<1 \quad$ Maximum

Median with a $5.3 \mathrm{~m} / \mathrm{s}$ wind

. $72 / 7$

20
$0.38 / 2.11$
3.12

3.12
1.9

3.12
1.9

1
3.05

$0.25 / 1.49$

1.31
$0.18 / 0.99$

12
1.9

1.9
$0.1 / 0.5$

0.79

0.79
10
6
Calculated median and 99-percentile

Maximum

Calculated median and 99-percentile

Maximum

Calculated median and 99-percentile

Median with a $3.4 \mathrm{~m} / \mathrm{s}$ wind

Calculated median and 99-percentile

Maximum

Calculated median and 99-percentile

Median with a wind of $2.6 \mathrm{~m} / \mathrm{s}$

Maximum
Median with a $4.7 \mathrm{~m} / \mathrm{s}$ wind

Berg 2000

Schneider 1935

Schneider 1935

Schneider 1935

Schneider 193

Stöcklin \& Bäumler 199

Stamp \& Lucas 1983 and unpubl. in Willson 1993

Stamp \& Lucas 1983 and unpubl. in Willson 1993

Stamp \& Lucas 1983 in Cain et al. 1998

Ridley 1930 in Müller-Schneider 1983

Müller-Schneider 1933 in Müller-Schneider 1983

Müller-Schneider 1983

Schneider 1935

Guttenberg 1926 in Müller-Schneider 1983

Müller-Schneider 1986

Müller-Schneider 1983

Ridley 1930 in Müller-Schneider 1983

Müller-Schneider 1986

Moor 1940 in Müller-Schneider 1983

Stapf 1887 in Müller-Schneider 1983

Ulbrich 1928 in Müller-Schneider 1983

Ulbrich 1928 in Müller-Schneider 1983

Stamp \& Lucas 1983 in Willson 1993

Bullock \& Clarke 2000

Soons \& Ozinga 2005

Bullock \& Clarke 2000

Soons \& Ozinga 2005

Soons \& Ozinga 2005

Antonovics \& Ellstrand 1985 in Willson 1993

Stöcklin \& Bäumler 1996

Soons \& Ozinga 2005

Sheldom \& Burrows 1973 in Cain et al. 1998

Soons \& Ozinga 2005

Stöcklin \& Bäumler 1996

Stergios 1976 in Willson 1993

Soons \& Ozinga 2005

Stöcklin \& Bäumler 199

Soons \& Ozinga 2005

Soons \& Ozinga 2005

Soons \& Ozinga 2005

Soons \& Ozinga 2005

Hegi 1906-1938 in Müller-Schneider 1986

Soons \& Ozinga 2005

McEvoy \& Cox 1987 in Willson 1993

Soons \& Ozinga 2005

Bergelson et al. 1993

Soons \& Ozinga 2005

Soons \& Ozinga 2005

Soons \& Ozinga 2005

Stöcklin \& Bäumler 199

Soons \& Ozinga 2005

Smith \& Kok 1984 in Willson 1993

Soons \& Ozinga 2005

Sheldom \& Burrows 1973 in Cain et al. 1998

Stöcklin \& Bäumler 1996

Klinkhammer et al. 1988 in Cain et al. 1998

Müller-Schneider 1986

Soons \& Ozinga 2005

Soons \& Ozinga 200

Soons \& Ozinga 2005

Stöcklin \& Bäumler 1996

Soons \& Ozinga 2005

Soons \& Ozinga 2005

Stöcklin \& Bäumler 199

Soons \& Ozinga 2005

Soons \& Ozinga 2005

Soons \& Ozinga 2005

Stöcklin \& Bäumler 1996

Stöcklin \& Bäumler 1996

Soons \& Ozinga 2005

Stöcklin \& Bäumler 1996

Stöcklin \& Bäumler 1996

Soons \& Ozinga 2005

Stöcklin \& Bäumler 199

Soons \& Ozinga 2005

Stöcklin \& Bäumler 1996

Stöcklin \& Bäumler 1996 


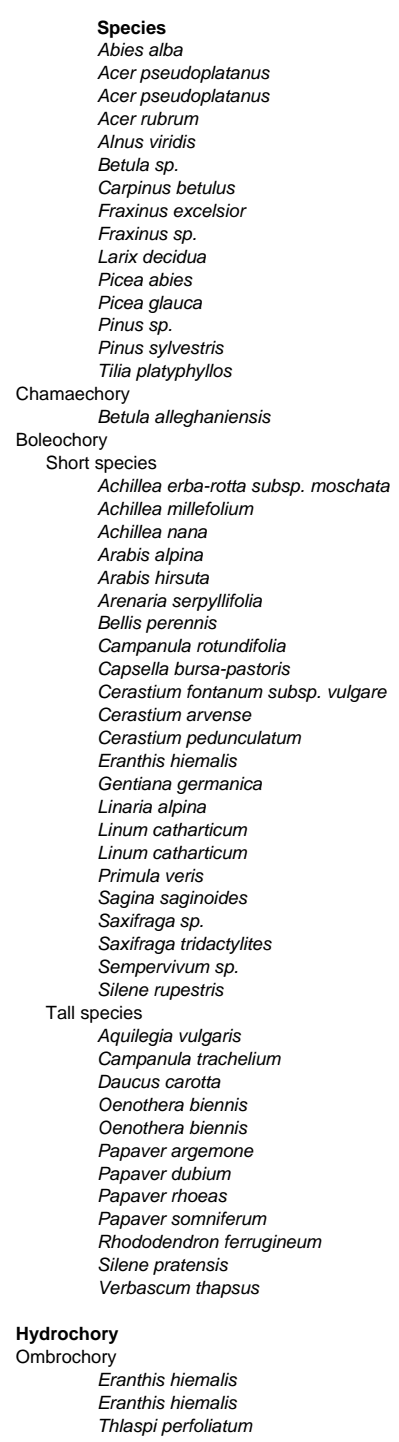

Distance [m]
$7000^{*}$

$5000^{*}$

$400-500^{*}$
$83 / 314 / 11^{\prime} 371$

70
$40 / 100$

$40 / 100$
130
$725^{*}$

$725^{\star}$
$40 / 100$

$40 / 100$
15

$1500^{\star} / 800^{*}$

$475^{\star}$
$40 / 100$

$2000^{*}$

80

$85 / 200$

$<1$
$0.07 / 0.39$
$4^{*}$

$4^{*}$
$<1$

$<1$
$0.09 / 0.47$

$0.03 / 0.13$

$0.02 / 0.09$

$0.07 / 0.35$

$0.05 / 0.23$

$0.03 / 0.16$

$<1$
$<1$

$<1$
$0.32 / 1.23$

1.2
$12 *$

$12^{*}$
$0.02 / 0.13$

$.41 / 0.63$

$0.03 / 0.12$

10 *

$40^{*}$
$0.02 / 0.11$

$<1$
$10 *$

$0.07 / 0.41$

$0.25 / 1.45$
$0.15 / 0.93$

$0.15 / 0.93$

$0.15 / 0.98$

$1.6 / 5$

$0.6 / 3.1$

$0.1 / 0.5$

$25^{*}$

$0.1 / 0.57$

$0.15 / 0.87$
Remarque (without indication, the values are measured) Maximum

Maximum

Maximum

Calculated median, 99-percentile et maximum

Maximum

Limit for the majority and maximum

Maximum

Maximum

Limit for the majority and maximum

Maximum

Maximum horizontal and vertical dispersion

Maximum

Limit for the majority and maximum

Maximum

Optimum and maximum

Maximum

Calculated median and 99-percentile

Maximum

Maximum

Calculated median and 99-percentile

Calculated median and 99-percentile

Calculated median and 99-percentile

Calculated median and 99-percentile

Calculated median and 99-percentile

Calculated median and 99-percentile

Maximum

Maximum

Median and maximum in natural wind

Maximum

Calculated median and 99-percentile

Maximum in dense vegetation or open micro-sites

Calculated median and 99-percentile

Maximum

Maximum

Calculated median and 99-percentile

Maximum

Calculated median and 99-percentile

Calculated median and 99-percentile

Calculated median and 99-percentile

Calculated median and 99-percentile

Mode an maximum

Mode an maximum

Mode an maximum

Calculated median and 99-percentile

Maximum with limited wind

Maximum

Calculated median and 99-percentile

Calculated median and 99-percentile

Maximum

Median and maximum dispersion under the rain

Maximum

(n)

Reference

Bouget \& Davy de Virville 1926 in Müller-Schneider 1983

Braun-Blanquet 1913 in Müller-Schneider 1986

Firbas 1935 in Müller-Schneider 1986

Higgins et al. 2003

Stöcklin \& Bäumler 1996

Greene \& Calogeropoulos 2002

Müller-Schneider 1986

Geiger 1960 in Müller-Schneider 1986

Greene \& Calogeropoulos 2002

Stöcklin \& Bäumler 1996

Braun-Blanquet 1913 in Müller-Schneider 198

Greene \& Johnson 1995 in Cain et al. 1998

Greene \& Calogeropoulos 2002

Firbas 1935 in Müller-Schneider 1983

Müller-Schneider 1986

Greene \& Johnson 1997

Stöcklin \& Bäumler 199

Soons \& Ozinga 2005

Stöcklin \& Bäumler 1996

Stöcklin \& Bäumler 1996

Soons \& Ozinga 2005

Soons \& Ozinga 2005

Soons \& Ozinga 2005

Soons \& Ozinga 2005

Soons \& Ozinga 2005

Soons \& Ozinga 2005
Stöcklin \& Bäumler 1996

Stöcklin \& Bäumler 1996

Emig et al. 1999

Verkaar et al. 1983

Stöcklin \& Bäumler 1998

Soons \& Ozinga 2005

Verkaar et al. 1983

Soons \& Ozinga 2005

Stöcklin \& Bäumler 1996

Stöcklin \& Bäumler 199

Soons \& Ozinga 2005

Stöcklin \& Bäumler 199

Stöcklin \& Bäumler 1996

Soons \& Ozinga 2005

Soons \& Ozinga 2005

Soons \& Ozinga 2005

Soons \& Ozinga 2005

Platt \& Weis 1977 in Willson 1993

Salisbury 1942 in Willson 1993

Salisbury 1942 in Willson 1993

Soons \& Ozinga 2005

Müller-Schneider 1983

Stöcklin \& Bäumler 199

Soons \& Ozinga 2005

Soons \& Ozinga 2005

Müller-Schneider 1936 in Müller-Schneider 1983 Emig et al. 1999

Müller-Schneider 1936 in Müller-Schneider 1983

Zoochory

Small animals
Dyszoochory

Fagus sylvatica

Helianthus annuus

Juglans nigra

Picea abies

Pinus strobus

Pinus jeffreyi

Pinus sp.

Quercus serrata

Quercus macrocarpa

Quercus petraea

Quercus $s p$.

Large animals

Corylus avellana

Fagus grandifolia

Fagus sylvatica

Juglans regia

Pinus albicaulis

Pinus cembra

Quercus palustris

Quercus $s p$.

Quercus petraea

Myrmecochory

Allium ursinum

Allium ursinum

Asarum canadense

Carex pilulifera

Chelidonium majus

Daphne striata

Euphorbia characias

Euphorbia characias

Euphorbia characias

Melica nutans

Mercurialis annua

Rhamnus alaternus

Sanguinaria canadensis

Sanguinaria canadensis

Viola hirta

Viola sp.

Various species

Various species

Various species

Various species

Various species

Various species

Various species

0.8

$4.13 / 13$
20
$15 / 38.1 / 151$
60
$15 / 30$
$21 / 69$
$1800^{*}$
$10 / 28.5$
$10 / 52$
18
$15.3 / 34$
$15000^{\star}$
$4000^{*}$
32
200
$100 / 3500$
$12^{\prime} 000^{*}$
$1100 / 1900$
$4000^{*}$
300

300

$1.52-4.61$

0.95

$0.75 / 1.4$

6.38

$2.1 / 4.6$

$2.1 / 9.4$

$0.79 / 1.6$

$70^{*}$
$3.4 / 14$

$1 / 5$

17

$2.57 / 6.7$

$70^{*}$
$0.75 / 1.5$

$70^{*}$

15

$0.96 / 77^{*}$

$0.64 / 2.7$

$0.53 / 5$.

$2.4 / 10$

$>1000^{*}$
Mean and maximum by rodents (Clethrionomys $s p$. and Apodemus sp.) Mean by nuthatch (Sitta europaea)

Minimum, mean and maximum by fox squirrels (Sciurus niger)

By great spotted woodpecker (Dendrocopos major) to open the cones Müller-Schneider 1983

$70 \%$ and maximum by rodents (Peromyscus sp. and Clethrionomys sp.)Abbott \& Quink 1970

Mean and maximim by rodents (chipmunk, Tamias $s p$.)

Maximal dispersion by red squirrels (Sciurus vulgaris orientis)

Mean and maximum by fox squirrels (Sciurus niger) S Stapanian \& Smith 1986

Maximum by rodents (Apodemus sp.)

Mean and maximum by rodents (Apodemus sp. and Clethrionomys sp.) Kollmann \& Schill 1996

Maximum dispersion by nutcrackers (Nucifraga caryocatactes)

Maximum dispersion by blue jays (Cianocitta cristata)

Dispersion by jay (Garrulus glandarius)

By carrion crow (Corvus corone) to break the nut

Mean and maximum by birds

Maximum dispersion by nutcrackers (Nucifraga caryocatactes)

Mean and maximum dispersion by birds

Maximum dispersion by jay (Garrulus glandarius)

Maximum by jay (Garrulus glandarius)

Different observations with Formica rufa

One observation with Formica cinerea

Mean and maximum

Mean and

One observation with Formica lugubris

Mean and maximum dispersed by Aphaenogaster senilis

Mean and maximum dispersed by Messor barbarus

Mean and maximum dispersed by Tapinoma nigerrimum

Maximum

Mean and maximum dispersed by Messor structor

Mean and maximum

Mean and maximum dispersed by Formica subsericea

Maximum

Maximum dispersion by Formica rufa

Maximum dispersion by Lasius niger

Mean and maximum in world literature

Mean and maximum in mesic deciduous forest in Japan

Mean and maximum in Oak-Pine temperate woodlands in USA

Mean and maximum in temperate deciduous forest in USA

Altitudinal shift by fox

Mean and maximum by birds

Mattes 1982

Müller-Schneider 1949

Müller-Schneider 1983

Koller-Schneider 1983

Müller-Schneider 1971

Müller-Schneider 197

Cain et al. 1998

Müller-Schneider 1963

Gomez et al. 2003

Ness 2004 in Ness et al. 2004

Johnsonn \& Adkinson 1985 in Clark et al. 1998

Hutchins \& Lanner 1982 in Cain et al. 1998

Sutter \& Ammann 1953 in Müller-Schneider 1986

Darley-Hill \& Johnson 1981 in Cain et al. 1998

Kjellsson 1985 in Ness et al. 2004

Gomez \& Espadaler 1998 in Ness et al. 2004

Gomez \& Espadaler 1998 in Ness et al. 2004

Gomez \& Espadaler 1998 in Ness et al. 2004

Senander 1906 in Bonn \& Poschold 1998

Lisci \& Pacini 1997 in Ness et al. 2004

Pudlo et al. 1980 in Cain et al. 1998 
Species

Prunus serotina

Rubus idaeus

Parthenocissus quinquefolia

Phytolacca american

Trillium grandifflorum

Vaccinium sp.

Vitis vulpina

Various species

Epizoochory

Small mammals

Agrimonia eupatoria

Daucus carotta

Geum rivale

Sanicula europaea

Torilis japonica

Triglochin palustris

Various species

Large mammals

Agrimonia eupatoria

Agrimonia eupatoria

Bidens $s p$.
Geum rivale

Jurinea cyanoides

Triglochin palustris

Various species

Various species

Various species

Anthropochory

Agochory

Bromus tectorum
Veronica filliform

Distance [m]
$7.1 / 35$
$>900^{*}$
$9 / 24$
33
$700 / 2500 / 3750^{*}$
500
24
$50 / 180$

Remarque (without indication, the values are measured)

Mean and maximum by birds

(Pyrrhocorax graculus)

Mean and maximum by birds

Maximum by birds

Median, 99-percentile and maximum by deer (Odocoileus virginianus)

Median by marten (Martes americana)

Maximum by birds

Maximum and extrem by blackbird (Turdus merula)

Maximum by wood mouse (Apodemum flavicollis)

Maximum by wood mouse (Apodemum flavicollis)

Maximum by wood mouse (Apodemum flavicollis)

Maximum by wood mouse (Apodemum flavicollis)

Maximum by wood mouse (Apodemum flavicollis)

Maximum by wood mouse (Apodemum flavicollis)

99-percentile by wood mouse (Apodemum flavicollis)

Maximum by fallow deer (Dama dama)

Maximum by cattle

Mean

Maximum by cattle

99-percentile and maximum

Maximum by fallow deer (Dama dama)

Mode and 99-percentile by sheep

Mode and 99-percentile by fallow deer (Dama dama)

Mode and 99-percentile by cattle

$65 / 435$

$125 / 850$

$\begin{array}{ll}6300 & \text { Calculated annual migration rate } \\ 4700 & \text { Calculated annual migration rate }\end{array}$
Reference

Smith 1975 in Cain et al. 1998

Müller-Schneider 1983

Hoppes 1988 in Cain et al. 1998

Hoppes 1988 in Cain et al. 1998

Vellend et al. 2003

Hickey et al. 1999

Hoppes 1988 in Cain et al. 1998

Müller-Schneider \& Lenggenhager 1959 in Bonn \& Poschold 1998

Kiviniemi \& Telenius 1998

Kiviniemi \& Telenius 1998

Kiviniemi \& Telenius 1998

Kiviniemi \& Telenius 1998

Kiviniemi \& Telenius 1998

Kiviniemi \& Telenius 1998

Mouissie et al. 2005a

Kiviniemi 1996 in Kiviniemi \& Telenius 1998

Kivieniemi \& Eriksson in Kiviniemi \& Telenius 1998

Bullock \& Primack 1977 in Cain et al. 1998

Kivieniemi \& Eriksson in Kiviniemi \& Telenius 1998

Eichberg et al. 2005

Kiviniemi \& Telenius 1998

Mouissie et al. 2005a

Mouissie et al. 2005

Mouissie et al. 2005a

Mack 1986 in Malcolm et al. 2002

Williamson et al. 2003 in Pyšek \& Hulme 2005

Supplementary references (not used in the article)

Abbott H.G. \& Qunik T.F. 1970. Ecology of eastern white pine caches made by small forest mammals. Ecology 51: 271-278. Berg H. 2000. Differential seed dispersal in Oxalis acetosella, a cleistogamous perennial herb. Acta Oecologica 21: 109-118.

Eichberg C., Storm C. and Schwabe A. 2005. Epizoochorous and post-dispersal processes in a rare plant species: Jurinea cyanoides (L.) Rchb. (Asteraceae). Flora 200: 477-489.

Emig W., Hauck I. und Leins P. 1999. Experimentelle Untersuchung zur Samenausbreitung vonErianthis hyemalis (L.) Salisb. (Ranunculaceae). Bull. Geobot. Inst. ETH 65:29-41

Gomez C. and Espadaler X. 1998. Myrmecochorus dispersal distances: a world survey. J. Biogeogr. 25: 573-580.

Gomez C., Pons P. and Bas J.M. 2003. Effects of the Argentine ant Linepithema humile on seed dispersal and seedling emergence of Rhamnus alaternus. Ecography 26: 532-538.

Hayashida M. 1988. Seed dispersal by red squirrels and subsequent establishment of Korean pine. Forest Ecol. Manag. 28: 115-129.

Jensen T.S. \& Nielsen O.F. 1986. Rodents as seeds dispersers in a heath oak wood succession. Oecologia 70: 214-221.

Müller-Schneider P. 1971. Beiträge zur Kenntnis der Samenverbreitung durch Ameisen. Ber. Schweiz. Bot. Ges. 80: 289-297.

Ness J.H. 2004. Forest edges and fire ants alter the seed shadow of an ant-dispersed plant. Oecologia 138: 448-454.

Ness J.H., Bronstein J.L., Andersen A.N. and Holland J.N. 2004. Ant body size predicts dispersal distance of ant-adapted seeds: implications of small-ant invasions. Ecology 85: 1244-1250.

Stapanian M.A. and Smith C.C. 1978. A model for seed scatterhoarding: coevolution of fox squirrels and black walnuts. Ecology 59: 884-896.

Stapanian M.A. and Smith C.C. 1986. How fox squirrels influence the invasion of prairies by nut-bearing trees. J. Mammal. 67: 326-332.

Verkaar H.J, Schenkeveld A.J. and van de Klashorst M.P. 1983. The ecology of short-lived forbs in chalk grasslands: Dispersal of seeds. New Phytol. 95: 335-344.

Willson M.F. 1993. Dispersal mode, seed shadows, and colonization patterns. Vegetatio 107/108: 261-280. 